\title{
Physical Activity, Physical Fitness, Gross Motor Coordination, and Metabolic Syndrome: Focus of Twin Research in Portugal
}

\author{
José António Ribeiro Maia, ${ }^{1}$ Daniel Santos, ${ }^{1}$ Duarte Luis de Freitas, ${ }^{2}$ and Martine Thomis ${ }^{3}$ \\ ${ }^{1}$ CIFI2D, Faculty of Sport, University of Porto, Porto, Portugal \\ ${ }^{2}$ Physical Education and Sports Department, University of Madeira, Madeira, Portugal \\ ${ }^{3}$ Faculty of Kinesiology and Rehabilitation Sciences, Department of Kinesiology, Katholieke Universiteit Leuven, \\ Leuven, Belgium
}

\begin{abstract}
A very brief history of Portuguese twin research in sport and human movement sciences is presented. Recruitment procedures, zygosity determination, and phenotypes are given for twins and their parents from the mainland, and Azores and Madeira archipelagos. Preliminary findings are mostly related to physical activity, health-related physical fitness, gross motor coordination, neuromotor development, and metabolic syndrome traits.
\end{abstract}

Keywords: Portugal, twins, physical activity, physical fitness, gross motor coordination, metabolic syndrome

\section{Brief History}

The Portuguese territory comprises a mainland located in the most western part of Europe, and two archipelagos both in the Atlantic Ocean: Azores (nine islands), and Madeira (two islands). The Portuguese twin research started in 1999 in the mainland by the first author (JARM), and then expanded to the Azores in 2001. In 2004, together with DLF, a new research branch started in Madeira. The focus of our research is on human physical activity and related traits, including physical growth, biological maturation, health perceptions, physical fitness, gross motor coordination, neuromotor development, body composition, bone, and metabolic syndrome (MetS). Our research started without funding. It was only in 2002 that the Portuguese Foundation for Science (FCT) gave a grant to JARM to study twins' physical activity, physical fitness, and body composition. Later on, in 2004, another grant from FCT allowed a joint venture with DLF, the late Gaston Beunen and Martine Thomis from the Katholieke Universiteit Leuven, Belgium, and colleagues from the University of Madeira Genetics Department. This 'research adventure', named genetic and environmental influences in physical activity, physical fitness and health (GEAFAS) (Madeira Family Study), was broad in its sampling schema (three-generation families) and scope (from quantitative to molecular genetics probing the value of several candidate genes). As no published twin research was available in the Portuguese language, we produced several papers regarding twin methodology and books/reports for Portuguese-speaking sport and human movement sciences researchers from Portugal, Brazil, Mozambique, and Angola (Maia, 2001; Maia et al., 2004, 2011; Sapage \& Maia, 2007). Furthermore, over the years, and in conjunction with the Portuguese Twin Group Register, four twin meetings were organized around the theme of active and healthy lifestyles.

\section{Recruitment Procedures}

As the main focus of our twin research is physical activity and related traits during the childhood and adolescent growth period, our target twin population was schoolaged children aged 4-18 years. Twin recruitment was made in several ways: first, through school lists and information from physical education teachers; second, through announcements in local newspapers and TV; third, through advertisements with local governmental bodies that facilitated all our twin meetings; fourth, through the Portuguese Twin Group.

RECEIVED 18 October 2012; ACCEPTED 30 October 2012. First published online 3 December 2012.

ADDRESS FOR CORRESPONDENCE: José António Ribeiro Maia, CIFI2D, Faculty of Sport, University of Porto, Rua Dr. Plácido Costa 91, 4200-450 Porto, Portugal. E-mail: jmaia@fade.up.pt 
TABLE 1

Domains, Test Batteries, Phenotypes, and Equipment

\begin{tabular}{|c|c|c|}
\hline Domains (test batteries) & Phenotypes & Equipment \\
\hline $\begin{array}{l}\text { Human physical growth } \\
\text { (International Biological Program) }\end{array}$ & $\begin{array}{l}\text { Height, weight, skinfolds, breaths, circumferences, } \\
\text { lengths }\end{array}$ & $\begin{array}{l}\text { Harpenden anthropometer, skinfold calipers, } \\
\text { and Seca scale }\end{array}$ \\
\hline Biological maturation & Bone age (Tanner-Whitehouse III) & Portable x-ray machine \\
\hline Body composition & $\begin{array}{l}\% \text { body fat, lean body mass, \% trunk, arms and legs } \\
\text { fat, and mass }\end{array}$ & Tanita BC-418 MA \\
\hline Bone accrual/health & Bone mineral content and density & DXA \\
\hline Physical activity & $\begin{array}{l}\text { Physical activity at work/school, leisure time, sport, } \\
\text { total; } \\
\text { Counts and METs (different intensity levels); } \\
\text { Steps and calories; } \\
\text { Approximate entropy patterns }\end{array}$ & $\begin{array}{l}\text { Questionnaires (Baecke et al., 1982; Godin \& } \\
\text { Shephard, 1985); accelerometer (TRITRAC } \\
\text { R3D); pedometer (Yamax DW-SW 700) }\end{array}$ \\
\hline $\begin{array}{l}\text { Physical fitness } \\
\text { (Fitnessgram test battery) }\end{array}$ & 1-mile run/walk, curl-ups, push-ups, trunk lift & Standard equipment provided by manufacturer \\
\hline $\begin{array}{l}\text { Gross motor coordination } \\
\text { (Körperkoordinationtest für Kinder: KTK) }\end{array}$ & $\begin{array}{l}\text { Backward balance (BB), hoping in one leg (HP), } \\
\text { shifting platforms (SP), jumping sideways (JS); } \\
\text { global motor coordination quotient (MCC) }\end{array}$ & Standard equipment provided by manufacturer \\
\hline $\begin{array}{l}\text { Neuromotor development } \\
\text { (Zurich neuromotor assessment) }\end{array}$ & $\begin{array}{l}\text { Purely motor tasks, fine motor task adaptive, dynamic } \\
\text { balance, and associated movements }\end{array}$ & $\begin{array}{l}\text { Standard equipment provided by manufacturer; } \\
\text { video camera Sony, } 50 \mathrm{~Hz}\end{array}$ \\
\hline Health-related quality of life & $\begin{array}{l}\text { Physical functioning, Role-physical, Bodily pain, } \\
\text { General health, Vitality, Social functioning, } \\
\text { Role-emotional, Mental health }\end{array}$ & SF-36 Questionnaire \\
\hline Physical self-concept & $\begin{array}{l}\text { Strength, body fat, physical activity, } \\
\text { endurance/fitness, sports competence, } \\
\text { coordination, appearance, flexibility, health }\end{array}$ & Physical Self-Description Questionnaire \\
\hline Metabolic syndrome & $\begin{array}{l}\text { Glucose, triglycerides, HDL-cholesterol, blood } \\
\text { pressure, waist girth }\end{array}$ & $\begin{array}{l}\text { OMRON - M10 IT; } \\
\text { Cholestech LDX analyzers }\end{array}$ \\
\hline
\end{tabular}

\section{Zygosity Assignment}

Two procedures were used to assess zygosity: (1) by the Peeters et al. (1998) questionnaire, that was later crossvalidated in Portugal using DNA data (Maia et al., 2007); (2) by DNA extraction with a method based on the use of Chelex resin. Genotyping was performed on an ABI 310 Genetic Analyzer (AB Applied Biosystems, Carlsbad, California, USA), according to the manufacturer's instructions. In all DNA samples, the analysis of 17 short tandem repeats autosomal (CSF1PO, D2S1338, D3S1358, D5S818, D7S820, D8S1179, D13S317, D16S539, D18S51, D19S433, D21S11, FGA, PD, PE, TH01, TPO, and VWA) and the Amelogenin locus (sex determination) was performed. Allele frequencies of the different genetic markers in the north and center of Portugal were used in the computation of probabilities of being monozygotic (MZ) twins.

\section{Measures}

Table 1 presents research domains, tests used, phenotypes, and equipment used in different twin studies. Twin research in Portugal has been initiated from scientists within the field of sport and movement sciences, with a special focus on children and adolescent populations. This initiation site' is reflected in the set of phenotypes under study that are mainly related to human growth, physical fitness, physical (in-)activity, neuromotor development, bone, and metabolic health.

\section{Main Findings}

Findings for distinctive research domains are summarized in Tables 2-5. Studies within the area of growth, physical fitness, physical activity, motor development, bone, and metabolic health require the measurement of young children and adolescents in a school or laboratory setting, with often multiple days of assessment. Therefore, sample sizes are often small in the different studies. Pearson correlation $(r)$, intra-class correlation coefficients $(t)$, or structural equation modeling were used to analyze twin covariation. In most studies, age effects are not modeled as a confounding factor within the structural equation-modeling framework. Given the small sample sizes in most studies, the analytical option was to first regress age and sex from each phenotype, and then compute heritabilities. Had our samples been larger, not only more precise genetic and environmental effects would be computed, but also more firm conclusions would be drawn.

\section{Physical Activity}

When using time-consuming interviews, pedometers and accelerometers to assess physical activity measures, our sample sizes are small. In children, genetic factors are small $\left(a^{2}\right.$ from $24 \%$ to $34 \%$ ) for the Godin and Shephard (1985) questionnaire phenotypes (low, moderate, and high intensity, as well as weekly total activity), and in line with the accelerometer data. These results were consistent in mainland and Azorean subjects. In adolescents, questionnaire data (Baecke) showed sex-specific estimates for sport 
TABLE 2

Physical Activity

\begin{tabular}{|c|c|c|c|c|c|c|c|c|c|c|c|c|}
\hline \multirow[b]{2}{*}{ Phenotypes } & \multirow[b]{2}{*}{ Specific measure } & \multicolumn{2}{|c|}{$\begin{array}{c}\text { Sample } \\
\text { size (pairs) }\end{array}$} & \multirow[b]{2}{*}{ Age } & \multirow[b]{2}{*}{ Location } & \multicolumn{2}{|c|}{$\begin{array}{c}\text { Pearson }(r) \text {, or intra-class correlation } \\
\text { coefficient }(t)\end{array}$} & \multicolumn{4}{|c|}{$\begin{array}{c}\text { Genetic and environmental } \\
\text { influences (\%) }\end{array}$} & \multirow[b]{2}{*}{ Reference } \\
\hline & & MZ & $\mathrm{DZ}$ & & & MZ & $\mathrm{DZ}$ & A & D & c & $\mathrm{E}$ & \\
\hline $\begin{array}{l}\text { Sport participation (Baecke et al., } \\
\text { 1982) }\end{array}$ & Arbitrary unit & 40 & 64 & $12-18$ years & Mainland & $\begin{array}{l}\text { Tetrachoric } \\
\quad \text { correlations from } \\
0.41-0.95\end{array}$ & $\begin{array}{l}\text { Tetrachoric } \\
\text { correlations from } \\
0.42-0.47\end{array}$ & $82(\mathrm{~m})$ & & & $18(\mathrm{~m})$ & Maia et al. (1999) \\
\hline $\begin{array}{l}\text { Weekly physical activity interview } \\
\text { (Godin \& Shephard, 1985) }\end{array}$ & Arbitrary units & 21 & 52 & 6-12 years & Azores islands & $t_{M Z}=0.86$ & $t_{\mathrm{DZ}}=0.62$ & 24 & & $71(f)$ & $\begin{array}{l}29(f) \\
76\end{array}$ & Maia et al. (2003) \\
\hline $\begin{array}{l}\text { School, leisure time, sport } \\
\text { participation, and total indices } \\
\text { (Baecke et al., 1982) }\end{array}$ & Arbitrary unit & 29 & 49 & $11-40$ years & Azores islands & $t_{M Z}: 0.72-0.92$ & $t_{D Z}: 0.48-0.65$ & $23-77$ & & $14-51$ & $8-28$ & Maia et al. (2001) \\
\hline \multirow[t]{4}{*}{$\begin{array}{l}\text { Sport participation, and (SPI) } \\
\text { leisure time (LTPA) indices (Baecke } \\
\text { et al., 1982) }\end{array}$} & Arbitrary unit & 99 & 104 & $11-25$ years & Mainland & $\begin{array}{l}r_{\mathrm{MZM}}=0.69 \\
r_{\mathrm{MZF}}=0.72\end{array}$ & $\begin{array}{l}r_{\mathrm{DZM}}=0.22 \\
r_{\mathrm{DZF}}=0.56 \\
r_{\mathrm{DZOS}}=0.31\end{array}$ & $63(\mathrm{~m})$ & & & $37(\mathrm{~m})$ & Maia et al. (2002) \\
\hline & & & & & & & & $32(f)$ & & $38(f)$ & $30(f)$ & \\
\hline & Arbitrary unit & & & & & $\begin{array}{l}r_{\mathrm{MZM}}=0.82 \\
r_{\mathrm{MZF}}=0.90\end{array}$ & $\begin{array}{l}r_{\mathrm{DZM}}=0.46 \\
r_{\mathrm{DZF}}=0.53 \\
r_{\mathrm{DZOS}}=0.49\end{array}$ & $68(\mathrm{~m})$ & & $20(\mathrm{~m})$ & $12(\mathrm{~m})$ & \\
\hline & & & & & & & & $40(f)$ & & $28(f)$ & $32(f)$ & \\
\hline \multirow{4}{*}{$\begin{array}{l}5 \text { days monitoring } \\
\text { Accelerometer (counts and METs) } \\
\text { Pedometer (steps and Kcal) }\end{array}$} & Counts & 32 & 19 & $12-18$ years & Mainland & & & 34 & & $20(1)$ & 66 & Oliveira \& Maia (2002) \\
\hline & METs & & & & & & & 20 & 41 & & 39 & \\
\hline & Steps & & & & & & & & & 90 & 10 & \\
\hline & Kcal & & & & & & & & & 80 & 20 & \\
\hline \multirow{3}{*}{$\begin{array}{l}\text { Weekly physical activity interview } \\
\text { (Godin \& Shephard, 1985) }\end{array}$} & LIPA & 32 & 69 & $6-12$ years & Mainland & - & - & 34 & & 64 & & Maia et al. (2004) \\
\hline & MPA & & & & & & & & & 82 & 18 & \\
\hline & VPA & & & & & & & 24 & & 67 & 9 & \\
\hline \multirow{4}{*}{$\begin{array}{l}5 \text { days monitoring } \\
\text { Accelerometer } \\
\text { (intensity, from low }=\text { till } 3 \mathrm{METs} \text {, to } \\
\text { very vigorous, }>9 \mathrm{METs} \text { ) }\end{array}$} & LPA & 18 & 13 & $6-12$ years & Mainland & $r_{\mathrm{MZ}}=0.89$ & $r_{\mathrm{DZ}}=0.77$ & & & & & Fernandes \& Maia (2006) \\
\hline & MPA & & & & & $r_{\mathrm{MZ}}=0.95$ & $r_{D Z}=0.88$ & & & & & \\
\hline & VPA & & & & & $r_{\mathrm{MZ}}=0.64$ & $r_{D Z}=0.49$ & & & & & \\
\hline & VVPA & & & & & $r_{\mathrm{MZ}}=0.76$ & $r_{D Z}=0.52$ & & & & & \\
\hline \multirow{4}{*}{$\begin{array}{l}5 \text { days monitoring } \\
\text { Accelerometer } \\
\text { (intensity, from low = till } 3 \mathrm{MET} \text {, to } \\
\text { very vigorous, }>9 \mathrm{METs} \text { ) } \\
\text { Pedometer (steps) }\end{array}$} & LIPA & 48 & 59 & $10-19$ years & Mainland & & & $79(\mathrm{~m})$ & & $7(\mathrm{~m})$ & $14(\mathrm{~m})$ & Sapage \& Maia (2007) \\
\hline & & & & & & & & $51(f)$ & & $40(f)$ & & \\
\hline & VVPA & & & & & & & $\begin{array}{l}72(m) \\
42(f)\end{array}$ & & 40 (1) & $\begin{array}{l}28(\mathrm{~m}) \\
58(\mathrm{f})\end{array}$ & \\
\hline & Steps & & & & & & & 44 & & 44 & 12 & \\
\hline 5 days monitoring & Counts (ApEn) & 77 & 85 & 8-18 years & Mainland & & & 44 & & 45 & 11 & Lima et al. (2010) \\
\hline
\end{tabular}

Accelerometer

approximate entropy (ApEn)

Note: $\mathrm{m}=$ male; $\mathrm{f}=$ female; $\mathrm{MZ}=$ monozygotic twin; $\mathrm{DZ}=$ dizygotic twin; $\mathrm{A}=$ additive genetic effects; $\mathrm{D}=$ nonadditive genetic effects; $\mathrm{C}=$ shared environmental effects; $\mathrm{E}=$ nonshared environmental effects including measurement error. 
TABLE 3

Health-Related Physical Fitness

\begin{tabular}{|c|c|c|c|c|c|c|c|c|c|c|}
\hline \multirow[b]{2}{*}{ Phenotypes } & \multirow[b]{2}{*}{ Specific measure } & \multicolumn{2}{|c|}{$\begin{array}{c}\text { Sample } \\
\text { size (pairs) }\end{array}$} & \multirow[b]{2}{*}{ Age } & \multirow[b]{2}{*}{ Location } & \multicolumn{4}{|c|}{$\begin{array}{l}\text { Genetic and } \\
\text { environmental } \\
\text { influences (\%) }\end{array}$} & \multirow[b]{2}{*}{ Reference } \\
\hline & & $M Z$ & $\mathrm{DZ}$ & & & A & $\mathrm{D}$ & C & $E$ & \\
\hline \multirow[t]{8}{*}{ Fitnessgram } & 1-mile run/walk & 21 & 52 & $6-10$ years & Azores islands & 58 & & 24 & 18 & \multirow[t]{8}{*}{ Maia et al. (2001) } \\
\hline & & 29 & 42 & $11-17$ years & & 54 & & 32 & 14 & \\
\hline & Push-up & 21 & 52 & 6-10 years & & 53 & & 31 & 16 & \\
\hline & & 29 & 42 & $11-17$ years & & 80 & & 0 & 20 & \\
\hline & Trunk-lift & 21 & 52 & 6-10 years & & 32 & & 41 & 27 & \\
\hline & & 29 & 42 & $11-17$ years & & 56 & & 31 & 13 & \\
\hline & Curl-up & 21 & 52 & $6-10$ years & & 38 & & 16 & 45 & \\
\hline & & 29 & 42 & $11-17$ years & & 30 & & 54 & 16 & \\
\hline \multirow[t]{4}{*}{ Fitnessgram } & 1-mile run/walk & 41 & 81 & $6-12 \mathrm{yr}$ & Mainland & 50 & & 37 & 13 & \multirow[t]{4}{*}{ Fernandes \& Maia (2006) } \\
\hline & Push-up & & & & & 74 & & 8 & 18 & \\
\hline & Trunk-lift & & & & & 34 & & 38 & 28 & \\
\hline & Curl-up & & & & & 75 & & 11 & 14 & \\
\hline
\end{tabular}

Note: $M Z=$ monozygotic twin; $D Z=$ dizygotic twin; $A=$ additive genetic effects; $D=$ nonadditive genetic effects; $C=$ shared environmental effects; $\mathrm{E}=$ nonshared environmental effects including measurement error.

\section{TABLE 4}

Gross Motor Coordination, and Neuromotor Development

\begin{tabular}{|c|c|c|c|c|c|c|c|c|c|c|c|}
\hline \multirow[b]{2}{*}{ Phenotypes } & \multirow[b]{2}{*}{ Specific Measure } & \multicolumn{2}{|c|}{$\begin{array}{l}\text { Sample } \\
\text { Size } \\
\text { (pairs) }\end{array}$} & \multirow[b]{2}{*}{ Age } & \multirow[b]{2}{*}{ Location } & \multicolumn{2}{|c|}{$\begin{array}{l}\text { Intraclass correlation } \\
\text { coefficient }(\mathrm{t})\end{array}$} & \multicolumn{3}{|c|}{$\begin{array}{l}\text { Genetic and } \\
\text { environmental } \\
\text { influences (\%) }\end{array}$} & \multirow[b]{2}{*}{ Reference } \\
\hline & & $M Z$ & $\mathrm{DZ}$ & & & $\mathrm{MZ}$ & $\mathrm{DZ}$ & A & C & $E$ & \\
\hline Gross motor & $\begin{array}{l}\text { Backward balance } \\
\text { Hoping in one leg } \\
\text { Shifting platforms } \\
\text { Jumping sideways } \\
\text { Global MC }\end{array}$ & 37 & 27 & 5-14 years & Mainland & $0.73-0.89$ & $0.61-0.69$ & $15-41$ & $46-58$ & $11-32$ & $\begin{array}{l}\text { Chaves et al. } \\
\text { (2012) }\end{array}$ \\
\hline Neuromotor & $\begin{array}{l}\text { Purely motor tasks } \\
\text { Dynamic balance } \\
\text { Static balance } \\
\text { Associated movements }\end{array}$ & 39 & 56 & 5-17 years & Mainland & $0.42-0.75$ & $0.41-0.56$ & & & & $\begin{array}{l}\text { Lopes et al. } \\
\qquad(2012)\end{array}$ \\
\hline
\end{tabular}

Note: $M Z=$ monozygotic twin; $D Z=$ dizygotic twin; $A=$ additive genetic effects, $D=$ nonadditive genetic effects, $C=$ shared environmental effects, $E=$ nonshared environmental effects including measurement error.

TABLE 5

Metabolic Syndrome

\begin{tabular}{|c|c|c|c|c|c|c|c|c|c|}
\hline \multirow[b]{2}{*}{ Phenotypes } & \multirow[b]{2}{*}{ Specific measure } & \multicolumn{2}{|c|}{$\begin{array}{c}\text { Sample } \\
\text { size (pairs) }\end{array}$} & \multirow[b]{2}{*}{ Age } & \multirow[b]{2}{*}{ Location } & \multicolumn{3}{|c|}{$\begin{array}{l}\text { Genetic and } \\
\text { environmental } \\
\text { influences (\%) }\end{array}$} & \multirow[b]{2}{*}{ Reference } \\
\hline & & $\mathrm{MZ}$ & $\mathrm{DZ}$ & & & A & C & $\mathrm{E}$ & \\
\hline \multirow[t]{5}{*}{ Metabolic syndrome } & WC & 84 & 123 & $3-18$ years & Madeira islands & 80 & & 20 & $\begin{array}{l}\text { Gonçalves et al. } \\
\text { (2011) }\end{array}$ \\
\hline & SBP & & & & & 59 & & 41 & \\
\hline & GLU & & & & & 55 & & 45 & \\
\hline & $\mathrm{HDL}$ & & & & & 34 & 44 & 22 & \\
\hline & TRG & & & & & 61 & & 39 & \\
\hline
\end{tabular}

Note: $M Z$ = monozygotic twin; $D Z=$ dizygotic twin; $A=$ additive genetic effects; $D=$ nonadditive genetic effects; $C=$ shared environmental effects; $E=$ nonshared environmental effects including measurement error.

participation, sports index (males: $a^{2}=63 \%$ and $c^{2}=37 \%$; females: $a^{2}=32 \%, c^{2}=38 \%, e^{2}=30 \%$ ), and leisure time physical activity index $\left(a^{2}=40 \%, c^{2}=28 \%, e^{2}=32 \%\right)$, which were coherent with accelerometer low and very vigorous physical activities - in males the genetic additive factors were always greater, and their magnitude was moderate-tohigh ( $a^{2}$ from $42 \%$ to $79 \%$ ). When studying physical activity patterns using approximate entropy as a suitable descriptor or a regular pattern of daily activities intensity, genetic factors account for about $50 \%$ of the total variation.

\section{Motor Performance}

Genetic factors are low to moderate in children's and adolescents' health-related physical fitness (see Table 3). 
Endurance running and muscular strength phenotypes had higher $a^{2}$ estimates. Gross motor coordination tests presented low genetic influence in children's performance (see Table 4). Twins' MZ and dizygotic (DZ) intra-class correlation coefficients suggest that neuromotor development from childhood to adolescence may be under genetic control, although environmental forces associated with daily living histories and twins' lifestyle may play an important role.

\section{MetS}

Within the Madeira Family Study (GEAFAS), DNA was collected for zygosity determination and future association studies with an array of candidate genes. From a vast set of data collected from all three-generation families, MetS information (systolic blood pressure, waist circumference, triglycerides, HDL-cholesterol, and glucose) is available from all subjects. Here, we only report twin data (see Table 5). In all five MetS indicators, MZ had higher intra-class correlations (from 0.56 to 0.81 ) than DZ twins (from 0.26 to 0.53 ). The prevalence of MetS (having, at least, any combination of three indicators) was very low: $\mathrm{MZ}=2.4 \%, \mathrm{DZ}=$ $5.3 \%$. A moderate-to-high additive genetic component was found in four of the five MetS indicators ( $a^{2}$ from $55 \%$ to $80 \%$; and $e^{2}$ from $20 \%$ to $45 \%$ ), but except HDL-cholesterol $\left(a^{2}=34 \%, c^{2}=44 \%, e^{2}=22 \%\right)$.

\section{Future Directions}

There is a strong need to merge all of our data sets to address the following issues: (1) to study in more detail physical activity patterns using accelerometer data; (2) to link physical activity levels with health-related physical fitness; (3) to study body composition and its relationship with physical activity levels; (4) to have a careful look at bone phenotypes; (5) to associate MetS indicators with physical activity and physical fitness; (6) to investigate the role of health perceptions in metabolic health and body composition; (7) to study the links of physical self-concept, body composition, and health-related physical fitness. The inter-relations among the phenotypes we examined suggest shared genetic and environmental factors for these phenotypes. In future studies, we plan to apply multivariate twin modeling to the covariations of these phenotypes. The Madeira Islands study includes three-generation families with phenotypes on human physical growth, body composition, biological maturation, physical activity, physical fitness, bone, health-related quality of life, and MetS and has also DNA data collected from 1,200 subjects. As such, an international collaboration is needed to extract the most from this unique data set. Furthermore, a call for education of Portuguese sport and human movement sciences researchers in the field of twin and family genetic methodologies is needed.

\section{Acknowledgment}

The authors would like to express their gratitude to YoonMi Hur for her contributions to the development of this manuscript.

\section{References}

Baecke, J., Burema, J., \& Frijters, J. (1982). A short questionnaire for the measurement of habitual physical activity in epidemiological studies. American Journal of Clinical $\mathrm{Nu}$ trition, 36, 936-942.

Chaves, R. N., Tani, G., Souza, M. C., Santos, D., \& Maia, J. (2012). Motor coordination variability. A study with a twin design. Brazilian Journal of Physical Education and Sport, 26, 301-311.

Fernandes, S. C. T. C., \& Maia, J. A. R. (2006). The relationship code of physical activity and health-related physical fitness. Genetic and environmental effects. Porto: Câmara Municipal de Cantanhede.

Godin, G., \& Shephard, R. (1985). A simple method to assess exercise behavior in the community. Canadian Journal of Applied Sport Sciences, 19, 141-146.

Gonçalves, P. J., Maia, J. A., Beunen, G. P., Carvalho, M. A., Brehm, A. M., . . . Freitas, D. L. (2011). Metabolic syndrome and its genetic factors. A study of twins from Madeira and Porto Santo islands, Portugal. In G. E. Baquet \& S. Berthoin (Eds.), Children and exercise XXV. The Proceedings of the 25th Pediatric Work Physiology Meeting (pp. 49-52). London: Routledge.

Lima, R. B. C. P., Fermino, R. C., Seabra, A., Garganta, R., \& Maia, J. A. R. (2010). Genetic and environmental components in physical activity patterns. Exploring the possibilities of approximate entropy. Brazilian Journal of Kinanthopometry and Human Performance, 12, 246254.

Lopes, A., Tani, G., Katzmarzyk, P., Thomis, M., \& Maia, J. (2012). Association between birth weight and neuromotor performance. A twin study. Manuscript in preparation.

Maia, J. A. R. (Ed.). (2001). Genetic aspects in physical activity. A univariate twin study. In Genetics and sports (pp. 65-83). Porto: FADE-UP.

Maia, J. A. R., Fernandes, S. C. T. C., Amorim, A., Alves, C., Gusmão, L., \& Pereira, L. (2007). Zygosity determination: from Peeter's questionnaire to DNA microsatélites. Revista Portuguesa de Ciências do Desporto, 7(2), 147-155.

Maia, J. A. R., Garganta, R., Seabra, A., \& Lopes, V. P. (2004). Heterogeneity in physical activity levels of 6- to 12-year-old children. A twin study. Portuguese Journal of Sport Sciences, 4, 39-50.

Maia, J., Loos, R., Thomis, M., Beunen, G., Vlietinck, R., Morais, F., \& Lopes, V. (1999). Genetic aspects of sports participation. A twin study. Revista Paulista de Educação Física, 13, 160-176. 
Maia, J., Lopes, V. P., \& Morais, F. P. (2001). Physical activity and health-related physical fitness. A genetic epidemiological approach in twins and their families from the Azores Islands. Porto: FADE-UP e DREFD-Azores.

Maia, J., Lopes, V. P., Seabra, A., \& Garganta, R. (2003). Genetic and environmental effects in physical activity and healthrelated physical fitness. A study in Azorean twins aged 6 to 12 years. Brazilian Journal of Science and Movement, 11, 33-44.

Maia, J. A. R., Seabra, A., Silva, R. M. G., Freitas, D. L., Gouveia, E. Q. R., \& Basso, L. (2011). Twin data analysis: A guided tour for sport sciences researchers. Brazilian Journal of Physical Education and Sport, 25, 351-368.
Maia, J., Thomis, M., \& Beunen, G. (2002). Genetic factors in physical activity levels. A twin study. American Journal of Preventive Medicine, 23, 87-91.

Oliveira, M. M. C., \& Maia, J. A. R. (2002). Physical activity multimodal assessment. An exploratory study using monozygotic and dizygotic twins. Porto: FADE-UP.

Peeters, H., Van Gestel, S., Vlietinck, R., Derom, C., \& Derom, R. (1998). Validation of a telephone zygosity questionnaire in twins of known zygosity. Behavioral Genetics, 28, 159163.

Sapage, I. N. L., \& Maia, J. A. R. (2007). Genetic and environmental factors in physical activity levels and patterns. A twin study. Lisboa: Visão e Contextos. 